\title{
Interleukin-12B Gene Polymorphism does not Confer Susceptibility to Graves' Ophthalmopathy in Japanese Population
}

\author{
YUJI HIROMATSU, TOMOKA FUKUTANI, MICHIKO ICHIMURA, TOKUNORI MUKAI, HIROO KAKU, \\ IKUYO MIYAKE AND KENTARO YAMADA
}

Division of Endocrinology and Metabolism, Department of Medicine, Kurume University School of Medicine, 67 Asahimachi, Kurume, Fukuoka 830-0011, Japan

\begin{abstract}
Graves' disease (GD) is an autoimmune disorder with genetic predisposition and frequently associated with Graves' ophthalmopathy (GO). Interleukin 12 (IL-12) is an important mediator of inflammatory immune responses and is expressed in the thyroid and orbit. IL-12B gene, which encodes the p40 subunit of IL-12, is located at chromosome 5q31-33. The aim of the present study was to investigate whether IL-12B gene polymorphism is associated with the development of GD or GO. IL-12B gene polymorphism was studied in Japanese GD patients $(\mathrm{n}=329)$ and healthy control subjects without anti-thyroid autoantibodies or a family history of autoimmune disorders $(\mathrm{n}=226)$. The A/C polymorphism at position 1188 of the $3^{\prime}$ untranslated region (3'UTR) of the IL-12B gene was analyzed using the polymerase chain reaction - restriction fragment length polymorphism method. There was no difference in allele or genotype frequency of the IL-12B gene polymorphism $(1188 \mathrm{~A} / \mathrm{C})$ between GD patients and control subjects. There was no association of the IL-12B gene polymorphism with ophthalmopathy, severity of hyperthyroidism or serum IgE levels. There was no association of the IL-12B gene polymorphism with serum IL-12 levels, which were significantly elevated in hyperthyroid phase of GD. In conclusion, IL-12B gene $1188 \mathrm{~A} / \mathrm{C}$ polymorphism is not associated with GD or GO susceptibility in Japanese.
\end{abstract}

Key words: Polymorphism, IL-12, Graves' disease, Graves' ophthalmopathy

(Endocrine Journal 53: 753-759, 2006)

GRAVES' disease (GD) is an autoimmune disorder frequently associated with ophthalmopathy [1]. Although the thyroid-stimulating hormone (TSH) receptor has been proposed as an autoantigen in GD patients, the nature of autoimmune reactions in the thyroid and orbit, and the mechanisms linking GD and Graves' ophthalmopathy (GO) have not been fully elucidated [2]. Several lines of research support the involvement of environmental factors, such as smoking, and genetic factors in both GD and GO $[2,3]$. The genetic sus-

Received: February 22, 2006

Accepted: July 7, 2006

Correspondence to: Dr. Yuji HIROMATSU, Division of Endocrinology and Metabolism, Department of Medicine, Kurume University School of Medicine, 67 Asahimachi, Kurume, Fukuoka 830-0011, Japan ceptibility of these diseases is thought to be polygenic. It has been reported that major histocompatibility complex (MHC) gene [3, 4], cytotoxic T lymphocyte antigen-4 (CTLA-4) gene [4-6], thyrotropin receptor (TSHR) gene [7], PTPN22 gene [8], CD40 gene [9, $10]$, interferon- $\gamma($ IFN- $\gamma)$ gene [11], tumor necrosis factor- $\alpha$ (TNF- $\alpha)$ gene $[12,13]$ and interleukin-13 (IL-13) gene [14] polymorphisms are associated with GD and their interactions may influence disease phenotype and severity [3]. However, their contribution to susceptibility to GO awaits confirmation.

Recent genome-wide researches have provided evidence for the linkage of GD to loci on multiple chromosomes, including loci on chromosome 5 in regions $5 q 31-q 33[15,16]$, which have been linked to autoimmune thyroid disorders including GD in Japanese and Chinese populations, but not in Caucasian popu- 
lations. This might suggest that these loci are specific to East Asian populations. The loci in regions 5q31q33 have also been identified as being susceptible to IgE synthesis $[17,18]$. This region encodes a cluster of cytokine genes, including IL-3, IL-4, IL-5, IL-9, IL12B and IL-13, which are involved in inflammation in both thyroid and orbit, and IgE synthesis [19].

IL-12 is an important immunoregulatory protein produced primarily by macrophages, B cells and other antigen-presenting cells [20]. It drives the differentiation of CD4+ T cells into T helper 1 (Th1) cells. IL-12 induces IL-2, IFN- $\gamma$ and TNF- $\beta$ from Th1 cells and IFN- $\gamma$ from NK (natural killer) cells. Increased serum levels of IL-12 have been reported in GD [21-23]. Furthermore, IL-12B mRNA expression has been demonstrated in thyroid tissues from patients with GD [24] and in orbital fat tissues from patients with active $\mathrm{GO}$ [25], but not in extraocular muscle tissues (EOM), or EOM-derived $\mathrm{T}$ cell lines from patients with GO undergoing corrective strabismus surgery [26]. Numerous single nucleotide polymorphisms (SNP) have recently been identified in the IL-12B gene [27] and the $1188 \mathrm{~A} / \mathrm{C}$ polymorphism in the $3^{\prime}$ untranslated region (3'UTR) of the IL-12B gene is associated with IL-12B mRNA expression levels [28] and IL-12 secretion levels from lipopolysaccharide (LPS) and purified protein derivative (PPD) stimulated peripheral blood mononuclear lymphocytes (PBML) [29]. Further, IL$12 \mathrm{~B}$ gene has been proposed as a susceptibility gene in type 1 diabetes mellitus [28, 30,31] with controversy [32-34], asthma [35] and hepatitis $C$ virus infection [36]. Thus, IL-12B gene might be a potential candidate gene contributing to the development of GD or influencing its clinical course. The aim of the present study was to investigate whether IL-12B gene polymorphism is associated with the development of GD and GO.

\section{Subjects and Methods}

\section{Subjects}

In total, 329 GD patients (74 males, 255 females; aged $11-83$ years, mean age $41.9 \pm 15.6$ years) being treated at Kurume University Hospital were enrolled in this study. GD diagnosis was determined by the presence of hyperthyroidism and serum anti-thyrotropin receptor antibodies and/or an increased ${ }^{123}$ I uptake ratio with diffuse uptake. Ophthalmopathy was classified according to the system recommended by the American Thyroid Association (ATA) Committee [37]. One hundred and three of the GD patients, 24 males and 79 females, showed ophthalmopathy defined as ATA class III or greater and were classified as GO. Two hundred and twenty-six patients showed no ophthalmopathy (ATA class 0), signs of ophthalmopathy without symptoms (ATA class I), or only soft tissue involvement (ATA class II). Two hundred and twentysix healthy unrelated Japanese volunteers (101 males and 125 females; aged 20-71 years, mean age 34.0 \pm 8.4 years) with no family history of autoimmune diseases and no detectable anti-thyroid autoantibodies were enrolled as control subjects. The study plan was reviewed and approved by the institutional review committee, and informed consent was obtained from all patients and control subjects.

\section{IL-12B gene polymorphism}

Genomic DNA extracted from peripheral blood was subjected to polymerase chain reaction (PCR) to amplify the polymorphic regions. The $\mathrm{A} / \mathrm{C}$ polymorphism in the 3'UTR $(1188 \mathrm{~A} / \mathrm{C})$ of the IL-12B gene was analyzed using a PCR-RFLP method previously described by Huang et al. [27]. PCR was performed using $50 \mathrm{ng}$ of genomic DNA, 1.25 units of Taq DNA polymerase (AmpliTaq, Applied Biosystems, Foster City, CA), $0.5 \mu \mathrm{M}$ of each primer (forward, 5'-TTTGGAGGAA AAGTGGAAGA-3'; reverse, 5'-AACATTCCATAC ATCCT-3'), $1.5 \mathrm{mM} \mathrm{MgCl}$ and $200 \mu \mathrm{M}$ of each deoxynucleotide triphosphate under the following conditions: 35 cycles of PCR consisting of $30 \mathrm{sec}$ at $95^{\circ} \mathrm{C}$, annealing for $30 \mathrm{sec}$ at $50^{\circ} \mathrm{C}$, extension for $1 \mathrm{~min}$ at $72^{\circ} \mathrm{C}$ and a final extension for $5 \mathrm{~min}$ at $72^{\circ} \mathrm{C}$ in a thermocycler (Gene Amp PCR system 9600, Perkin Elmer Applied Biosystems, Foster City, CA). The PCR products were digested using TaqI (Toyobo, Osaka, Japan), and the digested products were separated on a $3 \%$ agarose gel and identified by ethidium bromide staining. Some of the PCR products were directly sequenced using an ABI sequencer (ABI Prism ${ }^{\mathrm{TM}} 3100$ Genetic Analyzer, Perkin Elmer Applied Biosystems) to determine the A/C polymorphism in the 3'UTR $(1188 \mathrm{~A} / \mathrm{C})$ of the IL-12B gene. 


\section{Measurement of serum IL-12 levels}

Serum IL-12 levels were measured by a sandwich ELISA using a human IL-12 ELISA Kit (BioSource International, Camarillo, CA), according to the manufacturer's instructions.

\section{Laboratory tests}

Serum concentrations of free T3, free T4 and TSH were determined by enzyme immunoassays (EIAs). TSH receptor antibodies were measured using commercial kits [TRAb, Diasorin Inc., Stillwater, MN; thyroid stimulating antibody (TSAb), Yamasa Co., Tokyo, Japan]. Anti-thyroglobulin (TgAb) and anti-thyroid peroxidase antibodies (TPOAb) were measured by radioimmunoassay using commercial kits (RSR Limited, Cardiff, UK). The cut-off values for TRAb, TSAb, $\mathrm{TgAb}$ and TPOAb were $10 \%, 180 \%, 0.3 \mathrm{kU} / \mathrm{L}$ and $0.3 \mathrm{kU} / \mathrm{L}$, respectively. Serum $\operatorname{IgE}$ was measured by nephelometric assay (Dade Behring Marburg GmbH, Marburg, Germany).

\section{Statistical analysis}

The clinical data were expressed as the means \pm standard deviation (SD). Differences in the clinical data between groups were evaluated using a Student's $t$ test or Welch's $t$ test. The statistical significance of any differences in frequency between each polymorphic allele and genotype of the patient and control groups was evaluated using the $\chi^{2}$ test or Fisher's exact probability test. Linear correlation analysis was used to examine the correlation between IL-12 levels and other parameters. In this study, a $P$-value of $<0.05$ was considered statistically significant.

\section{Results}

Association between IL-12B gene polymorphisms and Graves' disease

The distributions of alleles for both groups (control and GD) were in good agreement with the HardyWeinberg equilibrium. There was no difference in the genotype frequency or the allele frequency between GD patients and the control subjects (Table 1).
Association between the IL-12B gene polymorphisms and ophthalmopathy

There was no significant difference in genotype or allele frequencies of IL-12B gene polymorphisms between the patients with evident ophthalmopathy (ATA class III or more; GO) and those without or with mild ophthalmopathy (ATA class 0 II; Table 2).

Association between the IL-12B gene polymorphisms and the severity of Graves' hyperthyroidism

There were no significant differences in the levels of serum $\mathrm{FT}_{4}, \mathrm{FT}_{3}$, TRAb or TSAb among the genotypes of $1188 \mathrm{~A} / \mathrm{C}$ polymorphism (Table 3 ). There were no differences in the serum IgE levels, or positive ratios (>170 kIU/l) among the genotypes of $1188 \mathrm{~A} / \mathrm{C}$ polymorphism (Table 4).

\section{Serum IL-12 levels in Graves' disease}

The mean serum IL-12 level in 109 patients with GD was significantly higher than that in 57 control subjects $(173 \pm 100 \mathrm{pg} / \mathrm{ml}$ vs. $96 \pm 38 \mathrm{pg} / \mathrm{ml}$, respectively, $\mathrm{P}<0.0001$, Fig. 1). The serum levels of IL-12 were significantly correlated with the serum FT3 $(\mathrm{r}=0.422, \mathrm{P}<0.0001)$, FT4 $(\mathrm{r}=0.304, \mathrm{P}=0.0013)$ and TRAb levels $(\mathrm{r}=0.265, \mathrm{P}=0.0063)$. The mean serum IL-12 level in hyperthyroid phase was significantly higher than that in euthyroid phase $(203 \pm 99 \mathrm{pg} / \mathrm{ml}$ vs. $115 \pm 54 \mathrm{pg} / \mathrm{ml}$, respectively, $\mathrm{P}<0.0001$, Fig. 1). There was no significant association of the IL-12B gene polymorphism with the serum IL-12 levels in hyperthyroid phase of GD or in control subjects (Fig. 1). There was no association of the IL-12 levels in hyperthyroid phase with ophthalmopathy $(195 \pm 88 \mathrm{pg} / \mathrm{ml}$ in ophthalmopathy group vs. $207 \pm 105 \mathrm{pg} / \mathrm{ml}$ in group without ophthalmopathy).

\section{Discussion}

Graves' disease is an organ-specific autoimmune disorder characterized by a diffuse goiter and thyroid hormone oversecretion as a result of thyrotropin receptor antibody stimulation. Although the etiology of GD remains unclear, it is believed to be caused by a complex interaction between genetic and environmental factors. Increased serum levels of IL-12 have been re- 
Table 1. IL-12B gene polymorphisms in patients with Graves' disease and healthy control subjects

\begin{tabular}{cccc}
\hline IL-12B gene polymorphism & $\begin{array}{c}\text { Graves' disease } \\
\mathrm{n}=329\end{array}$ & $\begin{array}{c}\text { Control subjects } \\
\mathrm{n}=226\end{array}$ & $\begin{array}{c}\chi^{2} \text { test } \\
P\end{array}$ \\
\hline A1188C $\quad$ Genotype frequencies & & & \\
AA & $77(24)$ & $39(17)$ & $\chi^{2}=3.063$ \\
AC & $162(49)$ & $120(53)$ & $P=0.2162$ \\
CC & $90(27)$ & $67(30)$ & \\
Allele frequencies & & & \\
A & $316(48)$ & $198(44)$ & $\chi^{2}=1.918$ \\
C & $342(52)$ & $254(56)$ & $P=0.1661$ \\
\hline
\end{tabular}

Values in parentheses are percentages of the group. $P$ values were calculated with $\chi^{2}$ test comparing patients with Graves' disease and healthy control subjects.

Table 2. Il-12B gene polymorphisms in patients with Graves' ophthalmopathy and in patients with Graves' hyperthyroidism without clinically evident ophthalmopathy

\begin{tabular}{|c|c|c|c|c|}
\hline \multirow{2}{*}{\multicolumn{2}{|c|}{ IL-12B gene polymorphism }} & \multicolumn{3}{|c|}{ Ophthalmopathy } \\
\hline & & \multirow{2}{*}{$\begin{array}{l}\text { ATA class III } \sim \text { VI } \\
n=103\end{array}$} & \multirow{2}{*}{$\begin{array}{l}\text { ATA class } 0 \sim \mathrm{II} \\
\mathrm{n}=226\end{array}$} & \multirow{2}{*}{$\begin{array}{l}\chi^{2} \text { test } \\
P\end{array}$} \\
\hline \multirow[t]{7}{*}{ A1188C } & Genotype frequencies & & & \\
\hline & $\mathrm{AA}$ & $22(21)$ & $55(24)$ & \multirow{3}{*}{$\begin{array}{l}\chi^{2}=0.442 \\
P=0.8017\end{array}$} \\
\hline & $\mathrm{AC}$ & $51(50)$ & $111(49)$ & \\
\hline & $\mathrm{CC}$ & $30(29)$ & $60(27)$ & \\
\hline & \multicolumn{4}{|l|}{ Allele frequencies } \\
\hline & A & $95(46)$ & $221(49)$ & $\chi^{2}=0.437$ \\
\hline & $\mathrm{C}$ & $111(54)$ & $231(51)$ & $P=0.5084$ \\
\hline
\end{tabular}

ATA class: classification by the American Thyroid Association

Values in parentheses are percentages of the group. $P$ values were calculated with $\chi^{2}$ test comparing patients with Graves' disease with ophthalmopathy and without evident ophthalmopathy.

Table 3. Association of IL-12B gene polymorphisms with laboratory features of untreated patients with Graves' disease

\begin{tabular}{crcccc}
\hline IL-12B gene polymorphism & $\mathrm{n}$ & FT3 $(\mathrm{pg} / \mathrm{ml})$ & FT4 $(\mathrm{ng} / \mathrm{dl})$ & TRAb $(\%)$ & TSAb $(\%)$ \\
\hline A1188C genotype & & & & & \\
AA & 49 & $14.2 \pm 6.9$ & $5.6 \pm 3.2$ & $38.0 \pm 25.3$ & $389 \pm 341$ \\
AC & 102 & $14.3 \pm 6.6$ & $5.3 \pm 2.9$ & $33.3 \pm 24.0$ & $483 \pm 750$ \\
CC & 59 & $13.1 \pm 6.9$ & $5.1 \pm 3.0$ & $33.1 \pm 25.2$ & $495 \pm 341$ \\
\hline
\end{tabular}

n, number of patients; FT3, free T3; FT4, free T4; TRAb, anti-thyrotropin receptor antibody; TSAb, thyroid stimulating antibody.

Table 4. Association of IL-12B gene polymorphisms with serum total IgE in patients with Graves' disease and control subjects

\begin{tabular}{|c|c|c|c|c|c|c|}
\hline \multirow{2}{*}{$\begin{array}{l}\text { IL-12B gene } \\
\text { polymorphism }\end{array}$} & \multicolumn{3}{|c|}{ Graves' disease $(n=297)$} & \multicolumn{3}{|c|}{ Control subjects $(n=224)$} \\
\hline & $\mathrm{IgE}>170 \mathrm{kIU} / \mathrm{l}$ & $\begin{array}{c}\text { Mean } \pm \text { SD } \\
(\mathrm{kIU} / \mathrm{l})\end{array}$ & $\begin{array}{c}\text { Median } \\
(\mathrm{kIU} / \mathrm{l})\end{array}$ & $\operatorname{IgE}>170 \mathrm{kIU} / \mathrm{l}$ & $\begin{array}{c}\text { Mean } \pm \text { SD } \\
(\mathrm{kIU} / \mathrm{l})\end{array}$ & $\begin{array}{r}\text { Median } \\
(\mathrm{kIU} / \mathrm{l})\end{array}$ \\
\hline \multicolumn{7}{|l|}{ A1188C genotype } \\
\hline AA & $21 / 68(31)$ & $326.0 \pm 696.2$ & 97.6 & $9 / 39(23)$ & $205.3 \pm 376.8$ & 76 \\
\hline $\mathrm{AC}$ & $55 / 146(38)$ & $311.3 \pm 513.8$ & 119.5 & $36 / 116(31)$ & $249.4 \pm 330.8$ & 84 \\
\hline $\mathrm{CC}$ & $28 / 83(34)$ & $334.3 \pm 693.9$ & 73.7 & $19 / 66(29)$ & $183.0 \pm 228.8$ & 89 \\
\hline total & $104 / 297(35)$ & $321.1 \pm 742.0$ & 105 & $64 / 221(29)$ & $222.1 \pm 443.2$ & 84 \\
\hline
\end{tabular}

Values in parentheses are percentages of the group.

There were no differences in the serum IgE levels, or positive ratios (>170 kIU/l) among the genotypes of 1188A/C polymorphism. 


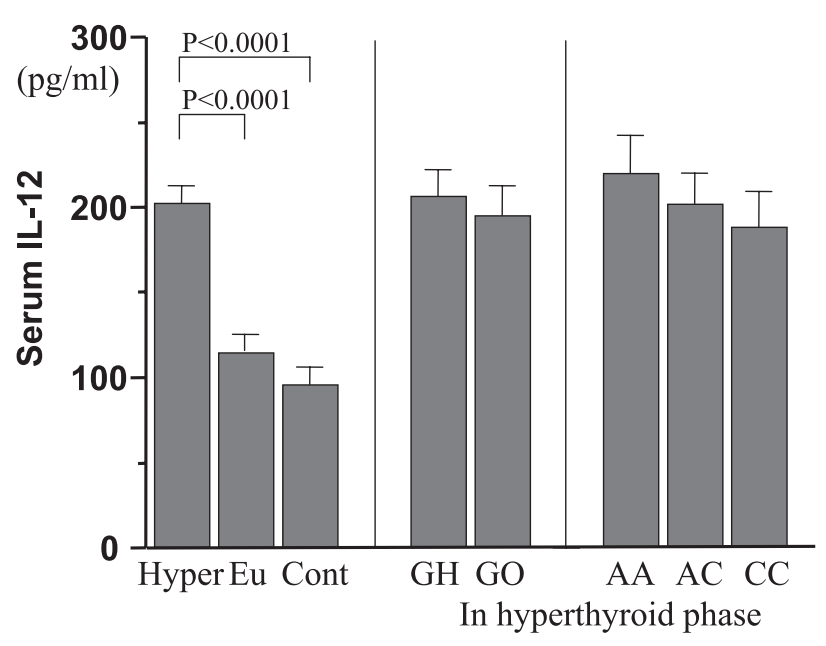

Fig. 1. Serum IL-12 levels in patients with Graves' disease and control subjects.

Hyper: hyperthyroid phase, Eu: euthyroid phase, Cont: control subjects, GH: Graves' disease without ophthalmopathy, GO: Graves' ophthalmopathy

ported in patients with GD [21-23]. The increased expression of IL-12 mRNA in thyroid and orbital fat tissues has been reported in GD and in active GO, respectively $[24,25]$. Furthermore, IL-12 is involved in the development of animal model of autoimmune thyroid disorders [38]. Therefore, IL-12 may play a role in the pathogenesis of GD and GO. Recent genome-wide researches have provided evidence for the linkage of GD to loci on chromosome 5 in regions $5 \mathrm{q} 31-\mathrm{q} 33$ in Japanese [15] and Chinese [16] populations. This region encodes a cluster of cytokine genes, including IL3, IL-4, IL-5, IL-9, IL-12B and IL-13, which are involved in inflammation and IgE synthesis [19]. Therefore, we hypothesized that IL-12B gene might be a potential candidate gene contributing to the development of GD or influencing its clinical severity and course, especially GO.

Recently, Ikeda et al. [39] performed a genetic association study using 90 GD patients and 123 control subjects in Japanese. They could not find any association between the IL-12B gene polymorphisms (A/T polymorphism in the intron 4 or $1188 \mathrm{~A} / \mathrm{C}$ in the 3'UTR) and GD. Dahlman et al. [33] also failed to show any association between the IL-12B gene 1188A/ $\mathrm{C}$ polymorphism and GD in white European patients. However, they did not investigate the association of the polymorphism with GO. In the present study, we confirmed the lack of association of IL-12B gene polymorphism with GD. Furthermore, our subanalysis showed no association of this polymorphism with GO, severity of hyperthyroidism, or serum IgE levels.

In the present study, we confirmed the increased levels of IL-12 in GD, especially in hyperthyroid phase. The IL-12 levels correlated with the serum FT3 levels, but not the presence of ophthalmopathy. Although there are conflicting reports on the relationship between the SNP and functional IL-12 gene expression on cell lines [28, 33], Yilmaz et al. [29] reported that LPS and PPD stimulation of PBML have induced higher levels of IL-12 in CC homozygotes in vitro. Bergholdt et al. [34] also reported the higher secretion of IL- 12 by stimulation of PBML with IFN $\gamma$ and LPS. The present study, however, showed no association of the elevated levels of serum IL-12 in hyperthyroid phase of GD with the genotypes of the IL-12B gene polymorphism.

In conclusion, the $1188 \mathrm{~A} / \mathrm{C}$ polymorphism in the 3'UTR of the IL-12B gene does not confer genetic susceptibility to GD or does not contribute to the development of ophthalmopathy in Japanese patients with GD. This SNP does not contribute to the elevated levels of serum IL-12 in hyperthyroid phase of GD. Further investigations of the other polymorphisms of the IL12B gene or haplotype analysis would be helpful to clarify the role of IL-12 in the etiology of GD and GO.

\section{Acknowledgements}

This work was supported in part by a grant-in-aid for Scientific Research from the Ministry of Education, Science, Sports and Culture, Japan.

\section{References}

1. Weetman AP (2000) Graves' disease. $N$ Engl J Med 26: 1236-1248.

2. Bartalena L, Pinchera A, Marcocci C (2000) Management of Graves' ophthalmopathy: reality and perspec- tives. Endocr Rev 21: 168-199.

3. Ban Y, Tomer Y (2005) Susceptibility genes in thyroid autoimmunity. Clin Dev Immunol 212: 47-58.

4. Simmonds MJ, Gough SC (2004) Unravelling the ge- 
netic complexity of autoimmune thyroid disease: HLA, CTLA-4 and beyond. Clin Exp Immunol 136: 1-10.

5. Vaidya B, Imrie H, Perros P, Dickinson J, McCarthy MI, Kendall-Taylor P, Pearce SH (1999) Cytotoxic T lymphocyte antigen-4 (CTLA-4) gene polymorphism confers susceptibility to thyroid associated orbitopathy. Lancet 354: 743-744.

6. Bednarczuk T, Hiromatsu Y, Fukutani T, Jazdzewski K, Miskiewicz P, Osikowska M, Nauman J (2003) Association of cytotoxic T-lymphocyte-associated antigen-4 (CTLA-4) gene polymorphism and nongenetic factors with Graves' ophthalmopathy in European and Japanese populations. Eur J Endocrinol 148: 13-18.

7. Hiratani H, Bowden DW, Ikegami S, Shirasawa S, Shimizu A, Iwatani Y, Akamizu T (2005) Multiple SNPs in intron 7 of thyrotropin receptor are associated with Graves' disease. J Clin Endocrinol Metab 90: 2898-2903.

8. Velaga MR, Wilson V, Jennings CE, Owen CJ, Herington S, Donaldson PT, Ball SG, James RA, Quinton R, Perros P, Pearce SH (2004) The codon 620 tryptophan allele of the lymphoid tyrosine phosphatase (LYP) gene is a major determinant of Graves' disease. J Clin Endocrinol Metab 89: 5862-5865.

9. Tomer Y, Concepcion E, Greenberg DA (2002) A C/T single-nucleotide polymorphism in the region of the CD40 gene is associated with Graves' disease. Thyroid 12: 1129-1135.

10. Mukai T, Hiromatsu Y, Fukutani T, Ichimura M, Kaku H, Miyake I, Yamada K (2005) A C/T polymorphism in the $5^{\prime}$ untranslated region of the CD40 gene is associated with later onset of Graves' disease in Japanese. Endocr J 52: 471-477.

11. Fukutani T, Hiromatsu Y, Kaku H, Miyake I, Mukai T, Imamura Y, Kohno S, Takane N, Shoji S, Otabe S, Yamada K (2004) A polymorphism of interferon gamma gene associated with changes of anti-TSH receptor antibodies induced by anti-thyroid drug treatment for Graves' disease in Japanese. Thyroid 14: 93-97.

12. Kamizono S, Hiromatsu Y, Seki N, Bednarczuk T, Matsumoto H, Kimura A, Itoh K (2000) A polymorphism of the $5^{\prime}$ flanking region of tumour necrosis factor alpha gene is associated with thyroid-associated ophthalmopathy in Japanese. Clin Endocrinol (Oxf) 52: 759-764.

13. Bednarczuk T, Hiromatsu Y, Seki N, Ploski R, Fukutani T, Kurylowicz A, Jazdzewski K, Chojnowski K, Itoh K, Nauman J (2004) Association of tumor necrosis factor and human leukocyte antigen DRB1 alleles with Graves' ophthalmopathy. Hum Immunol 65: 632-639.

14. Hiromatsu Y, Fukutani T, Ichimura M, Mukai T, Kaku H, Nakayama H, Miyake I, Shoji S, Koda Y, Bednarczuk $\mathrm{T}$ (2005) Interleukin-13 gene polymorphisms confer the susceptibility of Japanese populations to Graves' disease. J Clin Endocrinol Metab 90: 296-301.

15. Sakai K, Shirasawa S, Ishikawa N, Ito K, Tamai H, Kuma K, Akamizu T, Tanimura M, Furugaki K, Yamamoto K, Sasazuki T (2001) Identification of susceptibility loci for autoimmune thyroid disease to 5q31-q33 and Hashimoto's thyroiditis to 8q23-q24 by multipoint affected sib-pair linkage analysis in Japanese. Hum Mol Genet 10: 1379-1386.

16. Jin $\mathrm{Y}$, Teng $\mathrm{W}$, Ben $\mathrm{S}$, Xiong $\mathrm{X}$, Zhang J, Xu S, Shugart YY, Jin L, Chen J, Huang W (2003) Genomewide scan of Graves' disease: evidence for linkage on chromosome $5 \mathrm{q} 31$ in Chinese Han pedigrees. J Clin Endocrinol Metab 88: 1798-1803.

17. Lonjou C, Barnes $\mathrm{K}$, Chen $\mathrm{H}$, Cookson WO, Deichmann KA, Hall IP, Holloway JW, Laitinen T, Palmer LJ, Wjst M, Morton NE (2000) A first trial of retrospective collaboration for positional cloning in complex inheritance: assay of the cytokine region on chromosome 5 by the consortium on asthma genetics (COAG). Proc Natl Acad Sci USA 97: 10942-10947.

18. Soderhall C, Bradley M, Kockum I, Wahlgren CF, Luthman H, Nordenskjold M (2001) Linkage and association to candidate regions in Swedish atopic dermatitis families. Hum Genet 109: 129-135.

19. Xu J, Postma DS, Howard TD, Koppelman GH, Zheng SL, Stine OC, Bleecker ER, Meyers DA (2000) Major genes regulating total serum immunoglobulin E levels in families with asthma. Am J Hum Genet 67: 11631173.

20. Gately MK, Renzetti LM, Magram J, Stern AS, Adorini L, Gubler U, Presky DH (1998) The interleukin-12/ interleukin-12-receptor system: role in normal and pathologic immune responses. Annu Rev Immunol 16: 495-521.

21. Hidaka Y, Okumura M, Fukata S, Shimaoka Y, Takeoka K, Tada H, Kuma K, Amino N (1999) Increased serum concentration of interleukin-12 in patients with silent thyroiditis and Graves' disease. Thyroid 9: 149-153.

22. Tamaru M, Matsuura B, Onji M (1999) Increased levels of serum interleukin-12 in Graves' disease. Eur $J$ Endocrinol 141: 111-116.

23. Murakami S, Okubo K, Tsuji Y, Sakata H, Kikuchi M, Takahashi T, Kato T, Hirayama R (2005) Serum levels of interleukin-12 in Graves' disease and their dynamic changes after surgery. Surg Today 35: 1016-1020.

24. Ajjan RA, Watson PF, Weetman AP (1997) Detection of IL-12, IL-13, and IL-15 messenger ribonucleic acid in the thyroid of patients with autoimmune thyroid disease. J Clin Endocrinol Metab 82: 666-669.

25. Wakelkamp IM, Bakker O, Baldeschi L, Wiersinga WM, Prummel MF (2003) TSH-R expression and cytokine profile in orbital tissue of active vs. inactive Graves' ophthalmopathy patients. Clin Endocrinol (Oxf) 58: 280-287. 
26. Pappa A, Calder V, Ajjan R, Fells P, Ludgate M, Weetman AP, Lightman S (1997) Analysis of extraocular muscle-infiltrating $\mathrm{T}$ cells in thyroid-associated ophthalmopathy (TAO). Clin Exp Immunol 109: 362369.

27. Huang D, Cancilla MR, Morahan G (2000) Complete primary structure, chromosomal localisation, and definition of polymorphisms of the gene encoding the human interleukin-12 p40 subunit. Genes Immun 1: 515520.

28. Morahan G, Huang D, Ymer SI, Cancilla MR, Stephen K, Dabadghao P, Werther G, Tait BD, Harrison LC, Colman PG (2001) Linkage disequilibrium of a type 1 diabetes susceptibility locus with a regulatory IL-12B allele. Nat Genet 27: 218-221. Erratum in: Nat Genet 27: 346 .

29. Yilmaz V, Yentur SP, Saruhan-Direskeneli G (2005) IL-12 and IL-10 polymorphisms and their effects on cytokine production. Cytokine 30: 188-194.

30. McCormack RM, Maxwell AP, Carson DJ, Patterson CC, Middleton D, Savage DA (2002) The IL-12B 3' untranslated region DNA polymorphism is not associated with early-onset type 1 diabetes. Genes Immun 3: 433-435.

31. Windsor L, Morahan G, Huang D, McCann V, Jones T, James I, Christiansen FT, Price P (2004) Alleles of the IL-12B 3'UTR associate with late onset of type 1 diabetes. Hum Immunol 65: 1432-1436.

32. Johansson S, Lie BA, Thorsby E, Undlien DE (2001) The polymorphism in the 3 ' untranslated region of IL12B has a negligible effect on the susceptibility to develop type 1 diabetes in Norway. Immunogenetics 53: 603-605.

33. Dahlman I, Eaves IA, Kosoy R, Morrison VA, Heward J, Gough SCL, Allahabadia A, Franklyn JA, Tuomilehto
J, Tuomilehto-Wolf E, Cucca F, Guja C, IonescuTirgoviste C, Stevens H, Carr P, Nutland S, McKinney P, Shield JP, Wang W, Cordell HJ, Walker N, Todd JA, Concannon P (2002) Parameters for reliable results in genetic association studies in common disease. Nat Genet 30: 149-150.

34. Bergholdt R, Ghandil P, Johannesen J, Kristiansen OP, Kockum I, Luthman H, Ronningen KS, Nerup J, Julier C, Pociot F (2004) Genetic and functional evaluation of an interleukin-12 polymorphism (IDDM18) in families with type 1 diabetes. $J$ Med Genet 41: e39.

35. Randolph AG, Lange C, Silverman EK, Lazarus R, Silverman ES, Raby B, Brown A, Ozonoff A, Richter B, Weiss ST (2004) The IL-12B gene is associated with asthma. Am J Hum Genet 75: 709-715.

36. Yin LM, Zhu WF, Wei L, Xu XY, Sun DG, Wang YB, Fan WM, Yu M, Tian XL, Wang QX, Gao Y, Zhuang $\mathrm{H}$ (2004) Association of interleukin-12 p40 gene 3'untranslated region polymorphism and outcome of HCV infection. World J Gastroenterol 10: 2330-2333.

37. Werner SC (1977) Modification of the classification of the eye changes of Graves' disease: recommendation of the Ad Hoc Committee of the American Thyroid Association. J Clin Endocrinol Metab 44: 203-204.

38. Kimura H, Tzou SC, Rocchi R, Kimura M, Suzuki K, Parlow AF, Rose NR, Caturegli P (2005) Interleukin (IL)-12-driven primary hypothyroidism: the contrasting roles of two Th1 cytokines (IL-12 and interferongamma). Endocrinology 146: 3642-3651.

39. Ikeda Y, Yoshida W, Noguchi T, Asaba K, Nishioka T, Takao T, Hashimoto K (2004) Lack of association between IL-12B gene polymorphism and autoimmune thyroid disease in Japanese patients. Endocr J 51: 609613. 